\title{
Bioinformatics inspiring peptides from toxins as a new alternative in obesity
}

\section{treatment}

\author{
Bioinformática em peptídeos inspirados em toxinas como novas alternativas no tratamento de \\ obesidade \\ Péptidos inspiradores bioinformáticos de toxinas como nueva alternativa en el tratamiento de la \\ obesidade
}

\author{
Ana Paula de Araújo Boleti \\ ORCID: https://orcid.org/0000-0003-0253-8907 \\ Universidade Católica Dom Bosco, Brazil \\ E-mail: apboleti@yahoo.com.br \\ Thiago Antonio Almeida Rodrigues \\ ORCID: https://orcid.org/0000-0002-2443-8205 \\ Universidade Católica Dom Bosco, Brazil \\ E-mail: almeidarodrigues.th@gmail.com \\ Maria Eduarda Freitas Biembengute \\ ORCID: https://orcid.org/0000-0003-2561-0457 \\ Universidade Católica Dom Bosco, Brazil \\ E-mail: biembengutemaria@gmail.com \\ Lincoln Takashi Hota Mukoyama \\ ORCID: https://orcid.org/0000-0002-6977-3920 \\ Universidade Católica Dom Bosco, Brazil \\ E-mail: rsr.lincoln.mukoyama@gmail.com \\ Ludovico Migliolo \\ ORCID: https://orcid.org/0000-0002-6606-2189 \\ Universidade Católica Dom Bosco, Brazil \\ E-mail: ludovico.migliolo@gmail.com
}

\begin{abstract}
Obesity is a nutritional disorder caused by the excessive accumulation of white adipose tissue (WAT) in the body, which is characterized by a high body mass index and interferes with the body's energy balance. Obesity is a major risk factor for a number of different diseases, such as type 2 diabetes, cardiovascular disease, hypertension, fatty liver disease and some malignant tumors. The treatment of obesity primarily focuses on diet and physical exercise; when lifestyle changes fail, drugs and surgery will be considered as treatment options. At present, a number of so-called anti-obesity drugs have been developed, which affect digestion and absorption. These drugs can produce significant weight loss in the individual; however, some patients are unwilling to receive this type of treatment, due to side effects such as insomnia, hypertension and dizziness. This perspective shows that rational design is an alternative methodology based on native bioactive molecules for the development of analogous compounds, improved from the point of view of efficiency and side effects. We also show that the modification of peptides from animal toxins can be an interesting alternative in the treatment of obesity, since peptides from toxins have already shown significant antiinflammatory effects.
\end{abstract}

Keywords: Animal venom; Bioinspired peptides; Rational design; Inflammation; Obesity.

\section{Resumo}

A obesidade é um distúrbio nutricional causado pelo acúmulo excessivo de tecido adiposo branco (TAB) no corpo, que se caracteriza por um alto índice de massa corporal e interfere no equilíbrio energético do organismo. A obesidade é um importante fator de risco para uma série de doenças diferentes, como diabetes tipo 2, doenças cardiovasculares, hipertensão, doença hepática gordurosa e alguns tumores malignos. O tratamento da obesidade se concentra principalmente na dieta e exercícios físicos; quando as mudanças no estilo de vida falham, os medicamentos e a cirurgia serão considerados opções de tratamento. No momento, foram desenvolvidos vários dos chamados medicamentos contra a obesidade, que afetam a digestão e a absorção. Essas drogas podem causar perda significativa de peso no indivíduo; no entanto, alguns pacientes não desejam receber esse tipo de tratamento, devido a efeitos colaterais como insônia, hipertensão e tontura. Essa perspectiva mostra que o desenho racional é uma metodologia alternativa baseada em moléculas bioativas nativas para o desenvolvimento de compostos análogos, aprimorada do 
ponto de vista de eficiência e efeitos colaterais. Mostramos também que a modificação de peptídeos de toxinas animais pode ser uma alternativa interessante no tratamento da obesidade, uma vez que peptídeos de toxinas já apresentam importantes efeitos anti-inflamatórios.

Palavras-chave: Toxina animal; Peptídeos bioinspirados; Desenho racional; Inflamação; Obesidade.

\section{Resumen}

La obesidad es un trastorno nutricional causado por la acumulación excesiva de tejido adiposo blanco (WAT) en el cuerpo, que se caracteriza por un índice de masa corporal alto e interfiere con el equilibrio energético del cuerpo. La obesidad es un factor de riesgo importante para una serie de enfermedades diferentes, como la diabetes tipo 2 , las enfermedades cardiovasculares, la hipertensión, la enfermedad del hígado graso y algunos tumores malignos. El tratamiento de la obesidad se centra principalmente en la dieta y el ejercicio físico; cuando fallan los cambios en el estilo de vida, los medicamentos y la cirugía se considerarán como opciones de tratamiento. En la actualidad, se han desarrollado varios de los denominados medicamentos contra la obesidad, que afectan la digestión y la absorción. Estos medicamentos pueden producir una pérdida de peso significativa en el individuo; sin embargo, algunos pacientes no están dispuestos a recibir este tipo de tratamiento, debido a efectos secundarios como insomnio, hipertensión y mareos. Esta perspectiva muestra que el diseño racional es una metodología alternativa basada en moléculas bioactivas nativas para el desarrollo de compuestos análogos, mejorada desde el punto de vista de la eficiencia y los efectos secundarios. También mostramos que la modificación de péptidos de toxinas animales puede ser una alternativa interesante en el tratamiento de la obesidad, ya que los péptidos de toxinas ya han mostrado importantes efectos antiinflamatorios.

Palabras clave: Veneno animal; Péptidos bioinspirados; Diseño racional; Inflamación; Obesidad.

\section{Perspective}

Obesity is a clinical condition defined by the accumulation of excess body fat and an increased risk of developing other diseases, as indicated by the Body Mass Index (BMI) $\geq 30 \mathrm{~kg} \cdot \mathrm{m}^{-2}$ (Schütz, et al., 2021). According to the World Health Organization (WHO), it is estimated that in 2035 about $39 \%$ of the world's population will suffer from obesity, a disease capable of causing or aggravating more than 200 clinical conditions (Srivastava \& Apovian, 2018; Al-Goblan, et al., 2014). The clinical condition is linked to type 2 diabetes mellitus (DM2) and is associated with the development of insulin resistance (Al-Goblan, et al., 2014).

The increase in adipose tissue causes the release of free fatty acids, which activate nuclear factor7 Kappa B (NF-kB) and signaling pathway P38 Mitogen-Activated Protein Kinases (MAPK), which signal between the primary response proteins of myeloid differentiation 88 (MyD88) and TIR-domain-containing adapter-inducing interferon- $\beta$ (TRIF), mediating the Toll type 4 (TLR4) receptor expression activation cascade in adipocytes and macrophages. This process increases the stress of the endoplasmic reticulum (ER), producing reactive oxygen species, in addition to promoting the secretion of pro-inflammatory cytokines, such as chemotactic monocytic protein-1, tumor necrosis factor $\alpha$ (TNF- $\alpha$ ), interleukin (IL) -1 $\beta$ and IL-6 (Ahmed, et al., 2021).

Other studies demonstrate the relationship between the secretion of pro-inflammatory cytokines related to insulin resistance and the high production and deposition of free fatty acids and dietary lipids, which cause lipotoxicity in muscle cells and other organs. These fats are deposited in abnormal locations, causing the secretion of toxic lipids, such as ceramides and diacylglycerides, to alter the phosphatidylinositol 3-kinase (PI3K) pathway, and activate protein kinase C (PKC), CJun NTerminal kinase (JNK) and IkB kinase complex (IKK), generating stress in the ER and membrane stiffening, which induces inflammation and the onset of apoptosis (Ahmed et al., 2021). Other factors, such as the individual's reduction of physical activity and eating habits with high caloric density, contribute to the worsening of this condition. In contrast, carrying out physical exercises contributes to reducing the secretion of pro-inflammatory cytokines (Elias \& Vancea, 2019; Lopes, et al., 2017).

Appetite is a phenomenon that is highly regulated by a coordinated interaction between the central and peripheral nervous systems. Two signals inform the brain about the body's energy expenditure: these are short and long-term signals 
produced, respectively, by the gastrointestinal system and adipose tissue (Gao, et al., 2020). GLP-1 has many results for obesity treatments. In a three-month randomized phase 1 case study involving 22 obese patients with a percentage of BMI $\geq 35$ $\mathrm{kg} \cdot \mathrm{m}^{2}$, exanatide, a GLP-1 receptor agonist, was administered subcutaneously. In the first month, the dose was initially $5 \mu \mathrm{M}$ twice a day, and in the following two months the dose was $10 \mu \mathrm{M}$ twice a day. The treatment provided a decrease in the BMI rate equivalent to $-1.13 \mathrm{~kg} \cdot \mathrm{m}^{2}(4 \%)$, which may be effective for weight reduction in cases of obesity (Kelly, et al., 2013).

Leptin is another protein hormone secreted mainly by adipocytes that can act on hypothalamus neuronal cells, promoting hunger inhibition and increased energy expenditure. This protein decreases appetite by inhibiting neuropeptide $\mathrm{Y}$ (NPY) and increasing anorectic neuropeptides (Gao, et al., 2020). In addition to adipocytes, leptin can be secreted by the stomach when stimulated by intestinal peptides such as ghrelin, and insulin hormone after food intake (Figure 1). Similar to type 2 diabetes insulin resistance in patients, obese individuals may have resistance to leptin due to changes in the leptin receptor or deficiency in the transport system in the blood-brain barrier (Friedman, 2016). Leptin has also shown extensive regulatory activity in insulin signaling (Friedman, 2016).

Figure 1. The increase in adipocytes in adipose tissue in patients with obesity causes the release of pro-inflammatory cytokines such as TNF- $\alpha$, IL-6 and IL-1 $\beta$. Subsequently, leptin release is induced, which can also be stimulated by intestinal peptides such as ghrelin, which leads to inhibition of neuropeptide Y and thus reduces hunger. The same effect can be achieved through the use of GLP-1 receptor agonists, and rational designed peptides bioinspired by animal toxins can be used as a new and more efficient approach.

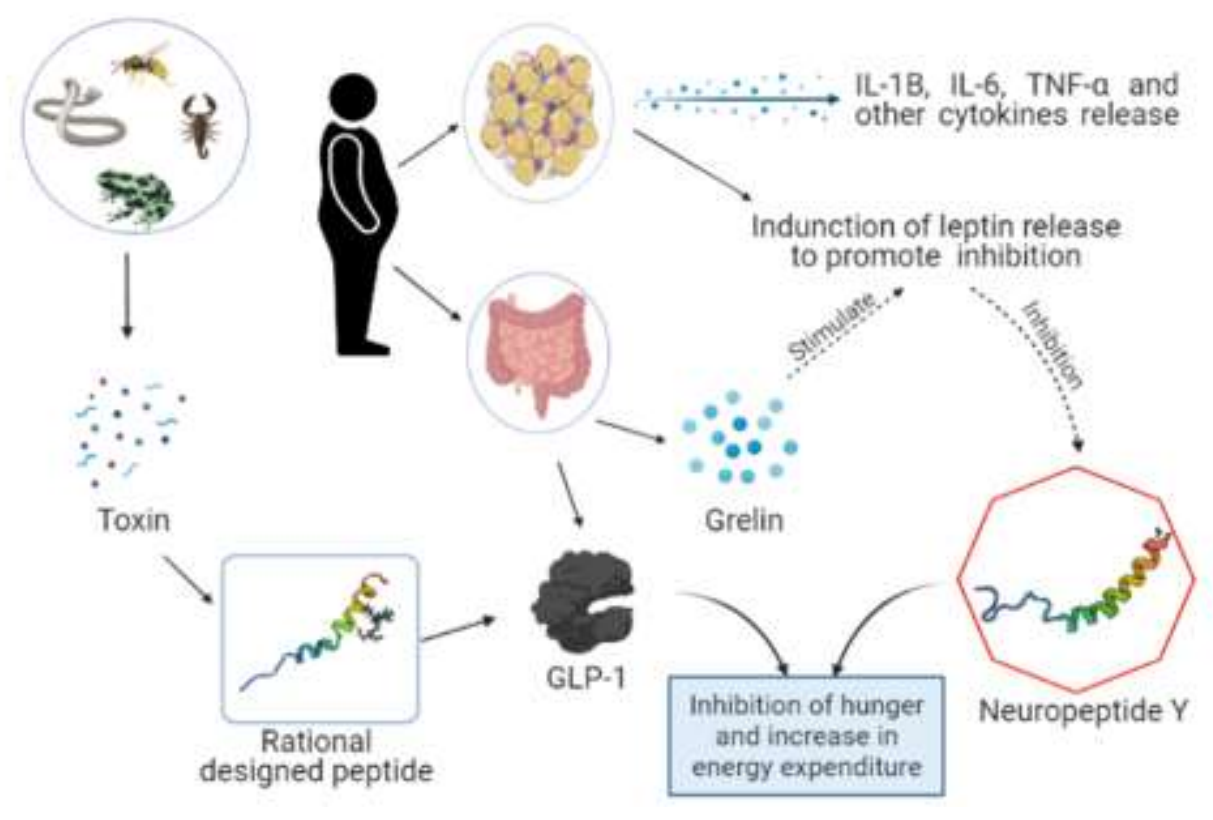

Source: Authors (2021).

The current pharmacological options are not sufficient to address the clinical heterogeneity of obesity treatment due to the various related diseases and the treatment's high cost (Srivastava \& Apovian, 2018). Thus, new strategies are needed to solve this problem, and the use of bioactive or synthetic peptides becomes a promising strategy. Several companies focus on the production of double or triple GLP-1 agonists, which are noted for DM2 and obesity treatment. Among the clinical-phase peptides, the GLP-1-glucose-dependent insulinotropic peptide (GIP) and GLP-1-glucagon double-agonist peptides, which are used in proof of concept in overweight and DM2 patients, stand out (Fosgerau \& Hoffmann, 2014). 
Given this interest, animal toxins represent a source of active biomolecules to be explored, having registered peptides with antibacterial, antiparasitic, antiviral, antifungal, antifreeze, antitumor, immunomodulatory and anti-inflammatory activity (Migliolo, et al., 2016; Yacoub, et al., 2020). In association with bioactive peptides, rational design methodology appears as the first analysis for the development of bio-inspired therapeutic molecules based on function-structure (Irazazabal, 2016).

Rational design is the in silico technique which, by modifications in the native peptide, promotes the construction of analogues. These can be explored through molecular modeling and molecular dynamics, in order to decrease the cost in bioprospection, optimizing the success of a synthetic peptide in the interaction with the target, in addition to lowering the cost of production by organic chemical synthesis (Figure 2). The method of comparative homology uses knowledge about native proteins with similarity to the primary sequence as a basis for a $3 \mathrm{D}$ construction model.

Figure 2. Process of peptide rational design using bioinformatic tools. Firstly, a target sequence such as a toxin is selected and the models are identified; then sequence alignments are made to start comparative homology modeling. This uses as a basis the knowledge of target sequences' template-based modeling, which seeks to construct a three-dimensional model with resemblance to the original primary sequence. The three-dimensional models are provided and validated by means of prediction servers and high confidence score averages, such as the Ramachandran Plot, which define the final model as reliable. When they are considered satisfactory, models undergo molecular dynamics and other in silico studies to understand the likely molecular behavior in different environments.

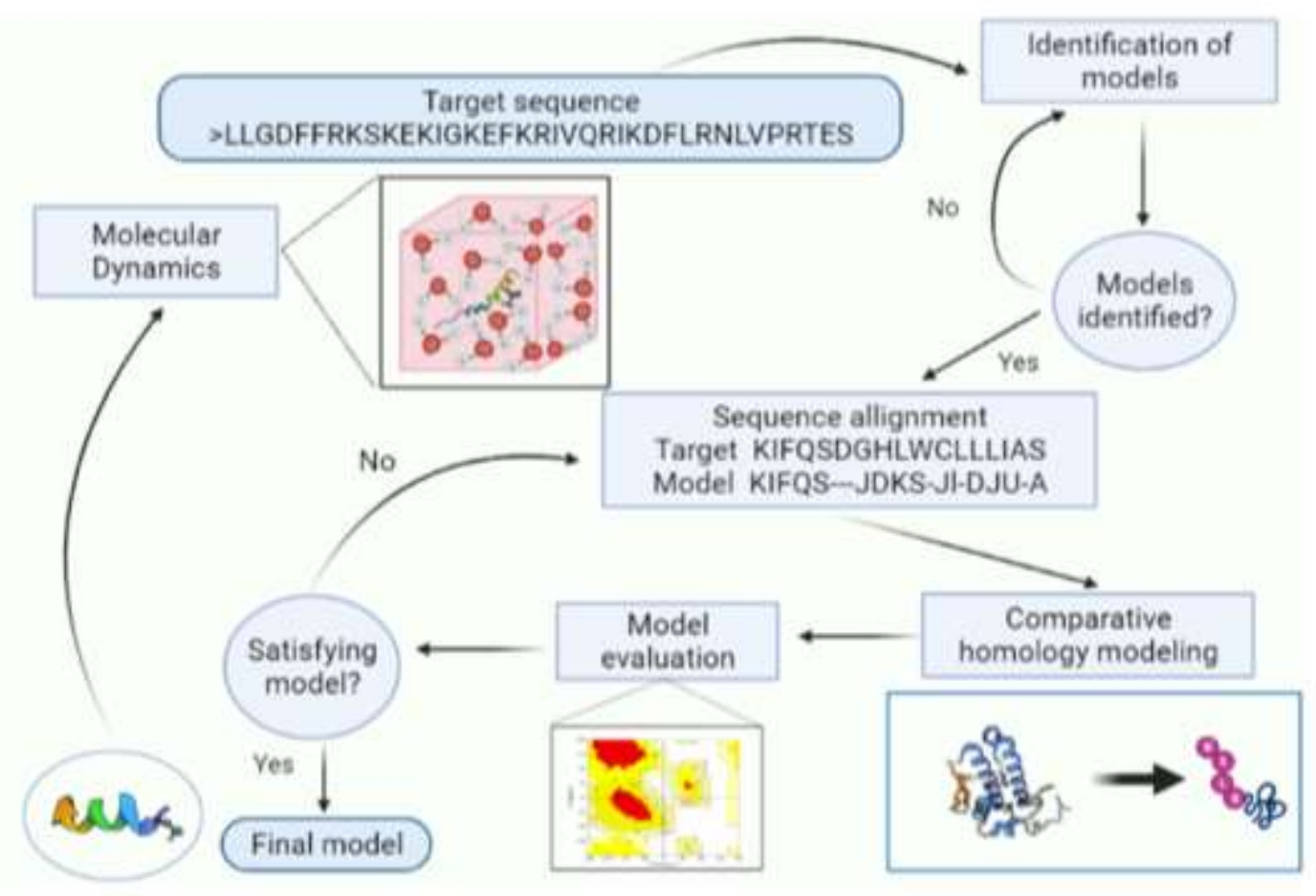

Source: Authors (2021).

So, the rational design technique can therefore be used for complementary studies with peptides from toxins that are deposited in databases to improve their pharmacological potential. Classic peptides have already been described in the literature showing a potential anti-inflammatory effect. Mastoparan peptide derived from Vespa simillima toxin, for example, with a sequence of just 14 amino acids $\left.\left(\mathrm{NH}_{2} \text {-INLKALAALAKKIL-NH}\right)_{2}\right)+4$ charge and $71 \%$ hydrophobicity, has shown antiinflammatory activity in reducing the release of pro-inflammatory cytokines and the expression of TLR4. This peptide 
dramatically reduces the expression of TNF $\alpha$ and IL-6 mRNA at a concentration of $40 \mu \mathrm{M}$ (Moreno \& Giralt, 2015; Hochberg, et al., 2021).

Other peptides, such as cathelidicin, have already been well described for their anti-inflammatory and anti-obesity properties. Cathelicidin-PY, derived from skin secretions of the frog Paa yunnanensis, for example, is a peptide with 29 amino acid residues $\left(\mathrm{NH}_{2}-\mathrm{RKCNFLCKLKEKLRTVITSHIDKVLRPQG-COOH),}+6\right.$ charge and $37 \%$ hydrophobicity. This peptide is capable of inhibiting the production inflammatory cytokines such as TNF- $\alpha$, IL-6, nitric oxide (NO) and monocyte chemoattractant protein-1 (MCP-1) at low concentrations $(5.8 \mathrm{nM})$, inhibiting the activation of TLR4 inflammatory response pathways induced by LPS. In addition, a recent clinical study suggested that the regulation of human cathelicidin expression in obese patients may be associated with bile acids, incretins or metabolic factors, and that cathelicidins may be adipokines at the interface between metabolism and the innate immune response (Hochberg, et al., 2021). Thus, Cathelicidin-PY becomes an interesting candidate for the development of peptide drugs to treat obesity and its comorbidities (Wei, et al., 2013).

Modifying these peptides could increase their anti-inflammatory activity and make them better candidates for obesity therapy. Studies with bioinspired peptides from toxins, with anti-obesity effects, are still lacking. Thus, it is suggested that rational design is a biotechnological tool that can benefit a number of patients through rational planning for peptide drugs, in the fight against inflammation and obesity, presenting potentially more effective and specific pharmacological alternatives to improve the chances of treatment success.

\section{Declaration of Consent / Ethical Approval:}

Not Required.

\section{Funding}

The author received no financial support for the research, authorship, and/or publication of this article.

\section{Disclosure}

The author reports no conflicts of interest in this work.

\section{References}

Ahmed, B., Sultana, R., \& Greene, M. W. (2021). Adipose tissue and insulin resistance in obese. Biomedicine \& Pharmacotherapy, 137, 111315. 10.1016/j.biopha.2021.111315

Al-Goblan, A. S., Al-Alfi, M. A., \& Khan, M. Z. (2014). Mechanism linking diabetes mellitus and obesity. Diabetes, metabolic syndrome and obesity: targets and therapy, 7, 587. 10.2147/DMSO.S67400

Fosgerau, K., \& Hoffmann, T. (2015). Peptide therapeutics: current status and future directions. Drug discovery today, 20(1), 122-128. 10.1016/j.drudis.2014.10.003

Friedman, J. (2016). The long road to leptin. The Journal of clinical investigation, 126(12), 4727-4734. 10.1172/JCI91578

Gao, Y., Yuan, X., Zhu, Z., Wang, D., Liu, Q., \& Gu, W. (2020). Research and prospect of peptides for use in obesity treatment. Experimental and Therapeutic Medicine, 20(6), 1-1. 10.3892/etm.2020.9364

Hochberg, A., Patz, M., Karrasch, T., Schäffler, A., \& Schmid, A. (2021). Serum levels and adipose tissue gene expression of cathelicidin antimicrobial peptide (CAMP) in obesity and during weight loss. Hormone and Metabolic Research, 53(03), 169-177. 10.1055/a-1323-3050

Irazazabal, L. N. (2016). Avaliação estrutural e funcional de novos peptídeos antimicrobianos obtidos a partir de desenho racional (Doctoral dissertation, Université Pierre et Marie Curie-Paris VI).

Kelly, A. S., Rudser, K. D., Nathan, B. M., Fox, C. K., Metzig, A. M., Coombes, B. J., \& Abuzzahab, M. J. (2013). The effect of glucagon-like peptide-1 receptor agonist therapy on body mass index in adolescents with severe obesity: a randomized, placebo-controlled, clinical trial. JAMA pediatrics, 167(4), 355360. 10.1001/jamapediatrics.2013.1045 
Research, Society and Development, v. 10, n. 14, e432101422057, 2021

(CC BY 4.0) | ISSN 2525-3409 | DOI: http://dx.doi.org/10.33448/rsd-v10i14.22057

Lopes, J. F., Matos, M. A., Magalhães, F. C., Esteves, E. A., Vieira, E. R., \& Amorim, F. T. (2017). Efeito de mudanças graduais de exercício físico e dieta sobre a composição corporal de obesos. Arquivos de Ciências da Saúde, 24(1), 93-97. 10.17696/2318-3691.24.1.2017.442

Migliolo, L., Felício, M. R., Cardoso, M. H., Silva, O. N., Xavier, M. A. E., Nolasco, D. O., \& Franco, O. L. (2016). Structural and functional evaluation of the palindromic alanine-rich antimicrobial peptide Pa-MAP2.Biochimica et Biophysica Acta (BBA)-Biomembranes, 1858(7), 1488-1498. 10.1016/j.bbamem.2016.04.003

Moreno, M., \& Giralt, E. (2015). Three valuable peptides from bee and wasp venoms for therapeutic and biotechnological use: melittin, apamin and mastoparan. Toxins, 7(4), 1126-1150. 10.3390/toxins7041126

Schütz, F., Figueiredo-Braga, M., Barata, P., \& Cruz-Martins, N. (2021). Obesity and gut microbiome: review of potential role of probiotics. Porto Biomedical Journal, 6(1). 10.1097/j.pbj.0000000000000111

Srivastava, G., \& Apovian, C. (2018). Future pharmacotherapy for obesity: new anti-obesity drugs on the horizon. Current obesity reports, 7(2), 147-161.

Vancea, D. M. M. (2019). A influ $\tilde{A}^{\mathrm{a} n c i a}$ do exercÃcio fãsico e suas vari $\tilde{A}_{i}$ veis sobre os marcadores inflamat $\tilde{A}^{3}$ rios em adultos obesos: uma revis $\tilde{A} £$ o sistem $\tilde{A}_{i}$ tica. RBPFEX-Revista Brasileira de Prescrição e Fisiologia do Exercício, 13(85), 852-861.

Wei, L., Yang, J., He, X., Mo, G., Hong, J., Yan, X., \& Lai, R. (2013). Structure and function of a potent lipopolysaccharide-binding antimicrobial and antiinflammatory peptide. Journal of Medicinal Chemistry, 56(9), 3546-3556. 10.1021/jm4004158 